\title{
PENGARUH PERBEDAAN INDIVIDUAL TERHADAP GAYA KEPEMIMPINAN
}

\author{
Friyen Riswono
}

friyenriswono@gmail.com

\begin{abstract}
Perbedaan individu seorang sangat penting dalam menentukan gaya kepemimpinan seorang pemimpin. Karena gaya kepemipinan seseorang pada dasarnya adalah sifat dari masing masing individu tersebut. Baik atau buruknya gaya kepemimpinan dapat diukur dengan hasil kerja yang akan dilaksanakan nantinya dan juga sebagai cara dari pemimpin melaksanakan kepemimpinannya. kepemimpinan merupakan kemampuan yang dimiliki seorang guru untuk mempengaruhi, menggerakkan, dan memotivasi siswanya agar mereka dengan semangat dan kesadaran yang tinggi mau berbuat dan menyumbangkan waktu, tenaga dan pikiran mereka dalam mencapai tujuan pembelajaran.
\end{abstract}

Kata Kunci : Perbedaan Individual, Kepemimpinan

\section{Pendahuluan}

Di dalam sebuah lingkungan kerja terdapat berbagai macam karakteristik seseorang. Sebagian besar orang menganggap di dalam lingkungan kerja tidak ada perbedaan antara individu satu dengan yang lainnya. Semua orang dianggap sama rata. Seseorang diberi tugas yang sama, menggunakan metode yang sama, teknik dan strategi yang sama, mendapat perlakuan yang sama dari pimpinan dan diharapkan mendapat hasil kerja yang semuanya baik.

Padalah seperti yang diketahui, setiap individu memiliki karakteristik yang berbeda-beda. Begitu pula dengan pegawai maupun pemimpin, sebagai individu, calon pemimpin yang satu dengan yang lainnya memiliki perbedaan. Perbedaan antar inidividu tersebut nantinya dapat berpengaruh bagaimana proses dan gaya kepemimpinan akan berlangsung. Untuk mencapai hasil 
pekerjaan yang optimal, oraganisasi harus mengetahui pemimpin seperti apa yang dibutuhkan dan berusaha membantu memenuhi kebutuhannya.

Seiring dengan perkembangan zaman, kepemimpinan secara ilmiah mulai berkembang bersamaan dengan pertumbuhan manajemen ilmiah yang lebih dikenal dengan ilmu tentang memimpin. Hal ini terlihat dari banyaknya literatur yang mengkaji tentang kepemimpinan dengan berbagai sudut pandang atau perspektifnya. Kepemimpinan tidak hanya dilihat dari baik saja, akan tetapi dapat dilihat dari penyiapan sesuatu secara berencana dan dapat melatih calon-calon pemimpin.

Sejarah timbulnya kepemimpinan, sejak nenek moyang dahulu kala, kerjasama dan saling melindungi telah muncul bersama-sama dengan peradapan manusia. Kerjasama tersebut muncul pada tata kehidupan sosial masyarakat atau kelompok-kelompok manusia dalam rangka untuk mempertahankan hidupnya menentang kebuasan binatang dan menghadapi alam sekitarnya. Berangkat dari kebutuhan bersama tersebut, terjadi kerjasama antar manusia dan mulai unsur-unsur kepemimpinan. Orang yang ditunjuk sebagai pemimpin dari kelompok tersebut ialah orang-orang yang paling kuat dan pemberani, sehingga ada aturan yang disepakati secara bersama-sama misalnya seorang pemimpin harus lahir dari keturunan bangsawan, sehat, kuat, berani, ulet, pandai, mempunyai pengaruh dan lain-lain. Hingga sampai sekarang seorang pemimpin harus memiliki syarat-syarat yang tidak ringan, karena pemimpin sebagai ujung tombak kelompok.

Kepemimpinan atau leadership merupakan ilmu terapan dari ilmu-ilmu social, sebab prinsip-prinsip dan rumusannya diharapkan dapat mendatangkan manfaat bagi kesejahteraan manusia (Moejiono, 2002). Ada banyak definisi kepemimpinan yang dikemukakan oleh para pakar menurut sudut pandang masing-masing, definisi-definisi tersebut menunjukkan adanya beberapa kesamaan.

\section{Rumusan Masalah}

Berdasarkan latar belakang permasalahan yang telah diungkapkan diatas, maka masih diperlukan penelitian yang mengkaji masalah pengaruh perbedaan 
individu terhadap gaya kepemimpinan. Dengan permasalahan yang ada kita harus tau bagaimana perbedaan individu tersebut dan apa dampaknya terhadap gaya kepemimpinan.

\section{Tujuan Penulisan}

Dengan adanya rumusan masalah diatas, tujuan dari artikel ini ialah agar apa yang dilakukan dapat mengarah ke sasaran dan mendapat hasil yang diharapkan, untuk menganalisis pengaruh (human relation) hubungan antar manusia dengan kondisi fisik lingkungan kerja terhadap kinerja pegawai dalam psikologi manajemen. 


\section{PEMBAHASAN}

\section{A. Ringkasan Artikel}

\section{a. Perbedaan Individual}

\section{1) Pengertian Perbedaan Individual}

Perbedaan individual (individualized instruction) merupakan pengajaran yang memperhatikan atau berorientasi pada perbedaan perbedaan individual anak. Perbedaan individual bukan pengajaran harus berdasarkan atas jalannya satu orang guru dengan satu orang murid, akan tetapi pengajaran dengan guru memberikan pelayanan yang berbeda pada setiap anak sesuai dengan perbedaan - perbedaan individual itu. Individualized instruction merupakan usaha melengkapi kondisi belajar yang optimum bagi setiap individu murid.(Hadi, 2017)

James D. Russell dalam Modular Instruction (1974) menyatakan bahwa Individualized instruction adalah suatu pengaturan yang memungkinkan setiap individu murid terikat dalam semua waktunya untuk belajar sesuatu yang berguna bagi dirinya sebagai individu. Landgren (1980:578) menyatakan perbedaan individual adalah menyangkut variasi yang terjadi, baik variasi pada fisik maupun psikologis.

Perbedaan individu adalah suatu perbedaan yang dimiliki oleh setiap individu baik fisik maupun non fisik yang menjadikan seseorang memiliki karakter/ciri-ciri yang berbeda antara satu dengan yang lainnya. Perbedaan individual merupakan factor penting sebagai dasar pengembangan Individualized instruction. Beberapa perbedaan yang sangat penting diperhatikan dalam proses pengajaran adalah perbedaan kemampuan dasar atau bakat, minat, kecepatan dan cara belajar anak. Setiap anak memiliki kemampuan dasar bawaannya berbeda maka minat anak dalam belajar akan berbeda juga. 


\section{2) Aspek - Aspek Perbedaan Individual}

Berikut beberapa aspek perbedaan individual peserta didik yaitu :

a) Perbedaan fisik - motoric

Perbedaan individual dalam fisik tidak hanya terbatas pada aspek aspek yang teramati oleh panca indera, seperti bentuk atau tinggi badan, warna kulit, warna mata atau rambut, jenis kelamin, nada suara atau bau keringat, melainkan juga mencakup aspek -aspek fisik yang tidak hanya dapat diamati melalui panca indera, tetapi hanya dapat diketahui setelah diadakannya pengukuran.

b) Perbedaan inteligensi

Inteligensi adalah salah satu kemampuan mental, pikiran atau intelektual dan merupakan bagian dari proses-proses kognitif pada tingkatan yang lebih tinggi. Secara umum inteligensi dapat dipahami sebagai kemampuan untuk beradaptasi dengan situasi yang baru secara cepat dan efektif, kemampuan untuk menggunakan konsep yang abstrak secara afektif, dan kemampuan untuk memahami hubungan dan mempelajarinya dengan cepat.

c) Perbedaan kecakapan bahasa

Bahasa merupakan salah satu kemampuan individu yang sangat penting dalam proses belajar disekolah. Kemampuan berbahasa adalah kemampuan seseorang untuk menyatakan buah pikirannya dalam bentuk ungkapan kata dan kalimat yang bermakna, logis dan sistematis.

d) Perbedaan psikologis

Perbedaan individual perserta didik juga terlihat dari aspek psikologinya. Ada anak yang mudah tersenyum, ada anak yang mudah marah, ada yang berjiwa social, ada yang sangat egoistis, ada yang 
cengeng, ada yang pemalas, ada yang rajin, ada yang pemurung, sebagainya.

\section{b. Kepemimpinan}

\section{1) Pengertian Kepemimpinan}

Menurut Terry dalam Sagala (2002:18) kepemimpinan adalah hubungan antara seseorang pemimpin dalam mempengaruhi orang lain untuk bekerja sama secara sadar dalam hubungan tugas untuk mencapai tujuan yang diinginkan pemimpin. Sedangkan kepemimpinan sebagai proses pemimpin menciptakan visi, mempengaruhi sikap, perilaku, pendapat, nilai-nilai, norma dan sebagainya dari pengikut untuk merealisasikan pengikut. Menurut Koontz dalam Sagala (2002:19) kepemimpinan adalah proses mempengaruhi orang-orang sehingga mereka mau berusaha dengan sepenuh hati dan antusias untuk mencapai tujuan.

Sedangkan dalam (Ermita, 2015) Kepemimpinan yang baik adalah kepemimpinan yang disenangi oleh bawahan dan dapat mempengaruhi pandangan bawahan secara dapat mempengaruhi pandangan bawahan secara positif terhadap pekerjaan yang dilakukannya positif terhadap pekerjaan yang dilakukannya. Bawahan akan merasa puas apabila pimpinan dapat melaksanakan tugasnya sebaik mungkin

Dari pendapat ahli diatas, dapat disimpulkan bahwa kepemimpinan merupakan kemampuan yang dimiliki seorang guru untuk mempengaruhi, menggerakkan, dan memotivasi siswanya agar mereka dengan semangat dan kesadaran yang tinggi mau berbuat dan menyumbangkan waktu, tenaga dan pikiran mereka dalam mencapai tujuan pembelajaran. 


\section{2) Gaya kepemimpinan}

Cara yang dilakukan seorang dalam melaksanakan atau menjalankan kepemimpinannya merupakan gaya kepemimpinan seorang tersebut. Dalam (Ermita, 2019) dalam jurnalnya mengemukakan bahwa gaya kepemimpinan merupakan cara atau kiat seorang pemimpin/guru dalam menghadapi bawahan/siswanya yang mempunyai perilaku dan kematangan yang berbeda-beda dalam rangka kegiatan belajar una mencapai tujuan yang telah ditetapkan. Oleh karena itu bagaimana gaya kepemimpinan seorang pemimpin akan di tentukan oleh perilaku dan kematangan siswanya. Selain itu gaya kepemimpinan juga di pengaruhi oleh perbedaan karakter dari masing masing individu tersebut.

Menurut (Nasrudin, 2010) Ada beberapa gaya kepemimpinan yang secara umum sering digunakan dalam kepemimpinan, yaitu :

\section{Otokratis}

Weber dalam Miftah (1983:89) merumuskan "kekuasaan itu sebagai suatu kemungkinan yang membuat seorang aktor di dalam suatu hubungan sosial be rada dalam satu jabatan untuk melaksanakan kein ginannya sendiri dan yang menghilangkan halangan-halangan". Jadi kekuasaan itu adalah suatu potensi pengaruh dari seorang pemimpin terhadap bawahannya untuk berbuat sesuai dengan keinginan pemimpin. Berdasarkan sumber dan bentuk kekuasaan menurut French dan Raven dalam Miftah (1983:92) dibagi atas lima sumber kekuasaan yaitu:

Kekuasaan paksaan, biasanya didasarkan dari rasa takut. Biasanya jenis ini mempunyai kemampuan untuk mengenakan hukuman, sanksi, dan pemecatan. 
Kekuasaan legitimasi, bersumber pada jabatan yang dipegang oleh pemimpin. Biasanya disini seorang pemimpin menggunakan kekuasaannya dengan cara mempengaruhi para bawahannya.

Kekuasaan keahlian, bersumber dari keahlian, kecakapan, atau pengetahuan yang dimiliki oleh seorang pemimpin yang diwujudkan lewat rasa hormat dan pengaruhnya terhadap orang lain.

Kekusaan penghargaan, bersumber atas kemampuan untuk menyediakan penghargaan atau hadiah bagi orang.

Kekuasaan referensi, bersumber pada sifat-sifat pribadi dari seorang pemimpin.

\section{Demokrasi}

Woods dalam Sagala (2002) "demokratis adalah pemimpin berkons ultasi dengan kelompok mengenai masalah yang menarik perhatian mereka dimana mereka dapat menyumbangkan sesuatu". Di sini pemimpin suatu proses dalam kegiatan pekerjaan dan tugas menerapkan sistem dimana dalam mengambil suatu keputusan, pimpinan tersebut meminta pendapat kepada para bawahannya.

\section{Laissez-faire}

Dalam gaya kepemimpinan ini sebenarnya pemimpin tidak memberikan pemimpinannya, dia membiarkan bawahannya berbuat sekehendaknya. Pemimpin sama sekali tidak memberikan control dan koreksi terhadap pekerjaan bawahannya. Pembagian tugas dan kerja sama diserahkan sepenuhnya kepada bawahannya tanpa petunjuk atausaran saran dari pemimpin. Dengan demikian mudah terjadi kekacauan kekacauan dan bentrokan - bentrokan. Tingkat keberhasilan anggota dan kelompok semata - mata disebabkan karena kesadaran dan dedikasi beberapa anggota kelompok, dan bukan karena pengaruhdari pemimpin. 
Struktur organisasinya tidak jelas atau kabur, segala kegiatan dilakukan tanpa rencana dan tanpa pengawasan dari pimpinan.

\section{Pseudo-demokratis}

Gaya ini disebut juga semi demokratis atau manipulasi diplomatic. Pemimpin yang menggunakan gaya pseudo-demokratis hanya tampaknya saja bersikap demokratis padahal sebenarnya dia bersikap otokratis. Misalnya jika ia mempunyai ide - ide, pikiran, atau konsepyang ingin diterapkan di lembaga Pendidikannya, maka hal tersebut akan dibicarakan dan dimusyawarahkan dengan bawahannya, tetapi situasi diatur dan diciptakan sedemikian rupa sehingga pada akhirnya bawahan didesak agar menerima ide atau pikiran tersebut sebagai keputusan bersama. Pemimpin ini menganut demokrasi semu dan lebih mengarah kepada kegiatan pemimpinyang otoriter dalam bentuk yang halus, samar - samar, dan yang mungkin dilaksanakan tanpa disadari bahwa tindakan itu bukan tindakan pimpinan yang demokratis.

\section{B. Pengaruh perbedaan individu terhadap gaya kepemimpinan}

Perbedaan individu seorang sangat penting dalam menentukan gaya kepemimpinan seorang pemimpin. Karena gaya kepemipinan seseorang pada dasarnya adalah sifat dari masing masing individu tersebut. Baik atau buruknya gaya kepemimpinan dapat diukur dengan hasil kerja yang akan dilaksanakan nantinya dan juga sebagai cara dari pemimpin melaksanakan kepemimpinannya. Jadi perbedaan individu seorang pemimpin sangat mempengaruhi apa dan bagaimana gaya kepemimpinan dari seorang pemimpin tersebut. 


\section{Kesimpulan}

Perbedaan individu adalah suatu perbedaan yang dimiliki oleh setiap individu baik fisik maupun non fisik yang menjadikan seseorang memiliki karakter/ciri-ciri yang berbeda antara satu dengan yang lainnya. Kepemimpinan merupakan kemampuan yang dimiliki seorang guru untuk mempengaruhi, menggerakkan, dan memotivasi siswanya agar mereka dengan semangat dan kesadaran yang tinggi mau berbuat dan menyumbangkan waktu, tenaga dan pikiran mereka dalam mencapai tujuan pembelajaran.

Perbedaan individu seorang sangat penting dalam menentukan gaya kepemimpinan seorang pemimpin. Karena gaya kepemipinan seseorang pada dasarnya adalah sifat dari masing masing individu tersebut. Baik atau buruknya gaya kepemimpinan dapat diukur dengan hasil kerja yang akan dilaksanakan nantinya dan juga sebagai cara dari pemimpin melaksanakan kepemimpinannya. 


\section{Daftar Pustaka}

Ermita. (2015). KEPEMIMPINAN GURU DALAM PELAKSANAAN TUGASNYA DI KELAS. XV(2), 31-41. Retrieved from http://103.216.87.80/index.php/pedagogi/article/view/5827/4556

Ermita. (2019). KONTRIBUSI GAYA KEPEMIMPINAN KEPALA SEKOLAH DAN MOTIVASI KERJA TERHADAP KINERJA GURU DI SEKOLAH MENENGAH ATAS NEGERI (SMAN) KECAMATAN KOTO TANGAH

KOTA PADANG. Jurnal Manajemen Pendidikan Dan Keislaman, 8(1), 107123. Retrieved from http://jurnal.uinsu.ac.id/index.php/hijri/article/download/5805/2667

Hadi, I. A. (2017). Pentingnya pengenalan tentang perbedaan individu anak dalam efektivitas pendidikan. 1(1), 71-91.

Nasrudin, E. (2010). Psikologi Manajemen. Bandung: Pustaka Setia. 